\title{
The Development of MANSAE as a Learning Media of Accounts for Vocational School Student of Accounting Program
}

\author{
Devi Nur Rahmawati Firdausi \\ Endang Sri Andayani \\ Universitas Negeri Malang \\ nrf.devii@gmail.com
}

\begin{abstract}
The objective of this research is to develop MANSAE (Making Accounting Newbies to Study Accounts Easily) as accounts learning media for accounting student of Vocational High School. MANSAE contains terms of accounts in Indonesian and English, normal balance of accounts, groups of accounts, classification of accounts in financial statement, and effect of service entity's financial transaction to accounts changes. This research uses Research and Development (R \& D) method adapted from Borg \& Gall's. These method are needs analysis, product development, expert validation, product revision I, try-out (small scale), product revision II, and final product. . Product validation was done by media expert and content expert, while try-out was done by $10^{\text {th }}$ grade of Accounting in SMKN 1 Turen. MANSAE get 97,61\% from media expert, 88,70\% from content expert, and $95,50 \%$ from limited user. The mean is $93,94 \%$, it means that from technical side, surface features, language and grammar, subject matter, and offline material is appropriate and suitable to use as accounts learning media for accounting newbies.
\end{abstract}

Keywords: media, mansae, account, account dictionary

Abstrak: Tujuan dari penelitian ini adalah untuk mengembangkan MANSAE (Making Accounting Newbies to Study Accounts Easily) sebagai media pembelajaran akun-akun untuk siswa SMK jurusan akuntansi. MANSAE berisi materi mengenai istilah akun dalam Bahasa Indonesia dan Bahasa Inggris, saldo normal akun, pengelompokan akun, klasifikasi akun dalam laporan keuangan, informasi singkat mengenai akun, dan pengaruh transaksi keuangan perusahaan jasa terhadap perubahan akun. Penelitian ini menggunakan metode pengembangan yang mengadaptasi langkahlangkah dari Borg \& Gall. Langkah-langkah yang dilaksanakan adalah analisis kebutuhan, pengembangan produk, uji validitas produk, revisi produk I, uji pengguna terbatas, revisi produk II dan produk akhir. Uji validitas produk dilakukan oleh ahli media dan ahli materi, sementara untuk uji pengguna terbatas dilakukan oleh 15 siswa kelas X Akuntansi SMKN 1 Turen. Media MANSAE mendapatkan penilaian dari ahli media sebesar $97,61 \%$, dari ahli materi sebesar $88,70 \%$, dan dari pengguna terbatas sebesar 95,50\%. Rata-rata dari ketiga penilaian tersebut adalah 93,94\%, yang artinya bahwa media MANSAE dari segi aplikasi, surface features, language and grammar, subject matter, dan offline material sudah sesuai dan layak digunakan sebagai media pembelajaran akun-akun untuk pemula di bidang akuntansi.

Kata kunci: media, mansae, akun, kamus akun

"Accounting consist of three basic activities-it identifies, recordings, and communicates the economic events of an organization to interested users" (Weygandt, 2011: 4). Artinya, akuntansi terdiri dari 3 (tiga) aktivitas dasar yaitu identifikasi, pencatatan, dan pengkomunikasian peristiwa-peristiwa ekonomi pada sebuah organisasi kepada pihak-pihak yang berkepentingan. Seseorang yang mendalami akuntansi di pendidikan formal, SMK Jurusan Akuntansi misalnya, harus menguasai 3 aktivitas dasar tersebut sebelum memasuki dunia kerja. 
Weygandt (2011: 55) menjelaskan bahwa dalam aktivitas pencatatan terdapat 3 langkah dasar, yaitu menganalisis efek yang ditimbulkan setiap transaksi terhadap akun-akun, memasukkan informasi akuntansi ke dalam jurnal, dan mentransfer/memindahkan informasi dari jurnal ke akun yang sesuai di buku besar. Singkatnya, ada 3 langkah dasar dalam pencatatan, yaitu analisis bukti transaksi, penjurnalan, dan posting ke buku besar. Dalam salah satu langkah tersebut, yaitu penjurnalan, dikenal istilah jurnal (journal). Jurnal merupakan catatan akuntansi pertama yang digunakan untuk mencatat, mengklasifikasikan, dan meringkas data keuangan (Ikhsan, 2012: 26). Wardhani (2013: 3) menyebutkan ada 5 fungsi jurnal, 3 fungsi diantaranya adalah fungsi historis, fungsi mencatat, dan fungsi informatif. Fungsi historis berarti bahwa jurnal memiliki peran untuk mencatat semua transaksi keuangan secara kronologis atau berurutan sesuai dengan tanggal terjadinya. Fungsi mencatat berarti jurnal berfungsi mencatat semua transaksi secara lengkap terperinci tanpa ada yang ketinggalan. Sementara fungsi informatif berarti jurnal berfungsi memberikan keterangan kegiatan perusahaan secara jelas. Dengan demikian, penguasaan kompetensi penjurnalan sangatlah penting, karena apabila salah dalam penjurnalan akan merusak fungsi historis, fungsi mencatat, dan fungsi informatif dari jurnal.

Samryn (2011: 84) menjelaskan agar tidak melakukan kesalahan penjurnalan, maka ada 5 (lima) hal yang sebaiknya dilakukan, 4 (empat) di antaranya: (1) menghafalkan nama-nama akun dalam neraca dan laporan laba rugi, sesuai bagan akun; (2) memahami arti, batasan, dan karakteristik tiap akun tersebut; (3) memahami mekanisme, kapan suatu akun harus dicatat di debet, dan kapan harus dicatat di kredit; dan (4) memahami penempatan tiap akun dalam neraca dan laba rugi, karena akun tidak boleh tertukar dalam laporan keuangan.

Selain 4 (empat) hal yang disebutkan Samryn, ada unsur lain yang paling mendasar dalam akuntansi, yaitu persamaan dasar akuntansi yang melaporkan kondisi atau posisi keuangan dan bisnis perusahaan yang meliputi posisi aktiva, kewajiban, dan modal pemilik (Ikhsan, 2012: 2). Persamaan dasar akuntansi diperlukan sebagai pengantar untuk mengenal karakteristik transaksi dan pengaruhnya pada akun dalam pembuatan jurnal. Sebagaimana Ikhsan, Handayati (2009: 30) menyatakan akuntansi pada dasarnya adalah aset, kewajiban, dan ekuitas. Jika seseorang ingin memahami istilah asing tersebut maka pintu untuk memahami akuntansi akan terbuka.

Berdasarkan penjelasan di atas, dapat ditarik kesimpulan bahwa seseorang yang belajar akuntansi harus memiliki kompetensi dasar: menghafalkan nama-nama akun, memahami pengklasifikasian akun berdasarkan jenisnya, memahami klasifikasi akun berdasarkan pelaporannya di laporan keuangan, memahami mekanisme pendebetan dan pengkreditan, 
serta memahami pengaruh transaksi keuangan terhadap posisi aset, kewajiban, dan ekuitas perusahaan.

Namun, berdasarkan wawancara dan pengamatan pembelajaran diketahui bahwa siswa di SMKN 1 Turen, SMK PGRI Turen, SMK Muhammadiyah 7 Gondanglegi, SMK Negeri 1 Malang, dan SMK PGRI 02 Malang mengalami kesulitan dalam mendebet/ mengkredit akun, menghafal nama-nama akun terutama dalam istilah asing/ Bahasa Inggris, mengklasifikasikan akun, serta mengidentifikasi pengaruh transaksi keuangan terahadap perubahan posisi akun. Sementara itu, guru tidak banyak memberikan alternatif sumber belajar lain sebagai pendukung sumber belajar utama. Agar siswa menguasai kompetensi dasar akuntansi serta membuat pembelajaran semakin menarik, maka diperlukan inovasi. Salah satu inovasi yang dapat dilakukan dengan penggunaan media pendukung pembelajaran MANSAE (Making Accounting Newbies to Study Accounts Easily) yang terdiri dari A-Dict, A-Link, dan A-Toon. A-Dict merupakan bagian dari MANSAE berupa kamus elektronik yang berisi berisi namanama akun, istilah asing akun, saldo normal, dan klasifikasi akun. A-Link merupakan bagian dari MANSAE yang terdiri dari narasi transaksi, narasi pengaruh terhadap akun, dan penjelasan mengenai transaksi dan pengaruhnya. Sementara A-Toon merupakan bagian dari MANSAE berupa materi mengenai akun-akun yang dikemas dalam bentuk cerita bergambar.

Sebelumnya, Restuningdiah (2012) telah mengembangkan buku saku kamus dan rumus akuntansi bilingual serta buku saku kamus dan rumus ekonomi. Buku saku kamus dan rumus akuntansi bilingual berisi istilah akuntansi dalam Bahasa Inggris-Bahasa Indonesia beserta penjelasannya, rumus dasar akuntansi, cara menghitung bunga obligasi, cara menghitung bunga wesel, cara menghitung deviden saham preferen kumulatif berpartisipasi, penghitungan GNP (Gross National Product), dan NNI (Net National Income). Berbeda dengan penelitian dan pengembangan milik Restuningdiah yang mengemas produknya dalam bentuk buku saku, pada peneltian dan pengembangan ini peneliti mengemas produknya dalam bentuk elektronik, yaitu A-Dict. A-Dict memuat akun dalam Bahasa Indonesia-Bahasa Inggris maupun Bahasa Inggris-Bahasa Indonesia, saldo normal akun, dan klasifikasi akun. A-Dict tidak sekompleks produk buku saku kamus milik Restuningdiah, karena sasaran media ini adalah pemula yang baru mempelajari akuntansi dan mengalami kesulitan dalam memahami saldo normal serta klasifikasi akun. Sehingga dalam A-Dict yang dikembangkan adalah media yang memuat nama-nama akun yang sering muncul dalam awal pembelajaran akuntansi.

A-Link terinspirasi dari kartu pintar yang telah dikembangkan oleh Hasan (2014). Pada penelitian dan pengembangan yang dilakukan oleh Hasan menghasilkan kartu pintar yang terdiri dari bukti transaksi yang berbentuk dokumen transaksi keuangan dan kartu perubahan 
akun yang terdiri dari akun harta, utang, ekuitas, pendapatan, serta beban. Perbedaan hasil pengembangan milik Hasan dengan A-Link antara lain: (1) transaksi keuangan disajikan dalam bentuk narasi agar lebih mudah dipahami karena sasaran produk adalah siswa yang baru mempelajari akuntansi; (2) perubahan akun terdiri dari nama masing-masing akun bukan kelompok akun; (3) dikemas dalam bentuk elektronik, dan (4) menyediakan pembahasan dari masing-masing transaksi keuangan dan pengaruhnya terhadap akun.

Sebelumnya Christiani (2012) telah mengembangkan media komik geografi dengan topik lingkungan. Materi yang dimuat dalam komik milik Christiani yaitu materi mengenai unsur biotik, abiotik, dan sosial budaya; arti penting lingkungan; kerusakan hutan; makhluk hidup yang terancam punah; hujan asam di daerah perkotaan; lubang ozon; dan pemanasan global. Perbedaan utama dengan A-Toon yang akan dikembangkan yaitu pada basis komiknya, yaitu A-Toon mengunakan basis elektronik. Selain itu, materi yang disampaikan juga berbeda, yaitu materi seputar akun dalam akuntansi.

Berdasarkan latar belakang di atas, maka pengembangan media pembelajaran diperlukan untuk menyediakan lebih banyak sumber belajar yang dapat digunakan siswa dalam pembelajaran dan membantu siswa mempelajari 5 (lima) kompetensi dasar akuntansi. Berbeda dengan penelitian sebelumnya, media yang akan dikembangkan bukan berupa media cetak namun berbasis elektronik dan bisa digunakan siswa di mana saja. Sehingga peneliti tertarik melakukan penelitian dengan judul "Pengembangan MANSAE (Making Accounting Newbies to Study Accounts Easily) sebagai Media Pembelajaran Akun-akun untuk Siswa SMK Jurusan Akuntansi”.

\section{METODE}

Prosedur pengembangan dan penelitian ini bersifat deskriptif dengan memodifikasi model pengembangan milik Borg and Gall untuk disesuaikan dengan keadaan lapangan, keterbatasan waktu, tenaga, dan biaya. Maka dari itu, dalam penelitian ini mengambil tujuh langkah dalam pengembangan media pembelajaran MANSAE. Rancangan model pengembangan yang akan digunakan dalam penelitian ini ditunjukkan pada gambar 1 . 


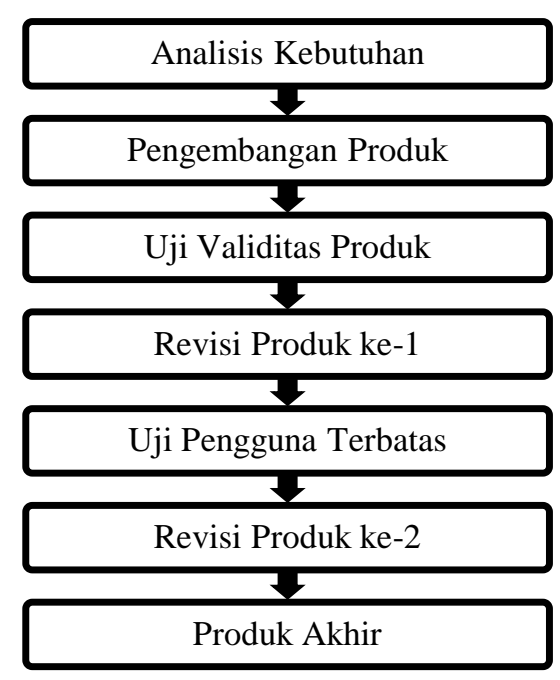

\section{Gambar 1. Bagan Langkah Model Pengembangan Borg \& Gall yang Dimodifikasi}

Uji coba produk dilakukan untuk mengetahui dan kemenarikan media pembelajaran yang dikembangkan berdasarkan perspektif pengguna (peserta didik). Dalam pengembangan MANSAE ini, menggunakan dua kali uji coba yaitu uji coba validator ahli dan uji pengguna terbatas. Subjek validasi ahli yang terdiri dari ahli materi dan ahli media, sementara subjek uji pengguna terbatas adalah peserta didik SMK jurusan akuntansi yang menempuh mata pelajaran akuntansi sebanyak 15 orang.

Instrumen penelitian ini berupa angket yang terdiri dari kolom check list meliputi daftar penilaian dan skala penilaiannya, serta lembar komentar dan saran dari validator. Angket ini akan menghasilkan 2 (dua) jenis data, yaitu data kuantitatif dan data kualitatif. Data kuantitatif diperoleh dari angket berupa penilaian dengan skala 1 sampai 5 terhadap media pembelajaran yang dihasilkan. Sementara data kualitatif berupa komentar dan saran yang dituangkan dalam angket uji coba ahli dan pengguna terbatas. Teknisk analisis untuk data kualitatif yang berupa kritik dan saran menggunakan teknik penarikan kesimpulan, sedangkan data kuantitatif dianalisis menggunakan teknik deskriptif persentase. Berikut ini rumus untuk menghitung persentase.

$$
\mathrm{P}=\frac{\mathrm{TSe}}{\mathrm{TSh}} \times 100 \%
$$

Keterangan

P : Persentase

TSe : Total skor empirik seluruh responden dalam 1 item

TSh : Total skor maksimal dalam 1 item

$100 \%$ : Konstanta

(Sumber: Akbar, 2013: 82) 
Setelah ditemukan persentase hasil subjek uji coba, selanjutnya dilakukan pemaknaan terhadap hasil tersebut dengan menggunakan tabel 1.

\begin{tabular}{ll}
\multicolumn{2}{c}{ Tabel 1. Presentase Hasil Penilaian } \\
\hline \multicolumn{1}{c}{ Persentase } & \multicolumn{1}{c}{ Keterangan } \\
\hline $\mathbf{8 1 - 1 0 0 \%}$ & Sangat valid \\
$\mathbf{6 1 - \mathbf { 8 0 \% } \%}$ & Valid \\
$\mathbf{4 1 - 6 0 \%}$ & Kurang valid \\
$\mathbf{2 1 - 4 0 \%}$ & Tidak valid \\
$\mathbf{0 0 - 2 0 \%}$ & Sangat tidak valid \\
\hline
\end{tabular}

(Sumber: Akbar, 2013: 42)

\section{HASIL dan PEMBAHASAN}

\section{HASIL}

Produk yang dikembangkan memiliki 4 (empat) menu utama dan 4 (empat) menu pendukung. 4 (empat) menu utama tersebut antara lain menu A-Dict (IN-EN), A-Dict (ENIN), A-Link, dan A-Toon. Sementara menu pendukung MANSAE terdiri dari menu Profile, Help, Credit, dan About.

Menu A-Dict (IN-EN) merupakan kamus akun dengan Bahasa Indonesia-Bahasa Inggris. Menu A-Dict (IN-EN) memuat nama-nama akun, istilah asing akun, saldo normal akun, penggolongan akun, klasifikasi akun dalam laporan keuangan, dan penjelasan singkat mengenai akun. Berikut ini spesifikasi menu A-Dict (IN-EN): (1) pada halaman awal menu A-Dict (IN-EN) terdapat judul menu A-DICT dan subjudul Indonesian-English, tombol menu untuk menuju ke halaman menu, serta tombol skip untuk menuju ke halaman petunjuk ADict; (2) pada halaman petunjuk terdapat judul "Petunjuk", uraian tentang petunjuk penggunaan menu A-Dict, tombol skip untuk melewati halaman petunjuk ke halaman list menu A-Dict (IN-EN), tombol next untuk menuju ke halaman petunjuk selanjutnya, tombol previous untuk menuju ke halaman petunjuk sebelumnya, serta tombol finish untuk menuju ke halaman list A-Dict; (3) pada halaman list terdapat judul halaman "List", tombol home untuk menuju ke halaman depan A-Dict (EN-IN), serta tombol abjad (A sampai Z) untuk menuju ke halaman daftar akun berdasarkan abjad; (4) pada halaman daftar akun terdapat tombol home untuk menuju ke halaman depan menu A-Dict (IN-EN), tombol list untuk menuju ke halaman list/daftar abjad, serta tombol akun yang sudah diurutkan berdasarkan abjad untuk menuju ke halaman penjelasan akun; (5) pada halaman penjelasan akun terdapat judul akun, penjelasan mengenai istilah asing akun, saldo normal akun, kelompok akun, dan pelaporan akun di laporan keuangan, tombol abjad untuk menuju ke halaman daftar akun, tombol home untuk menuju ke halaman awal menu A-Dict (IN-EN), tombol list untuk menuju ke halaman daftar abjad (list), serta tombol more info untuk menuju ke halaman penjelasan singkat mengenai 
akun terkait; dan (6) pada halaman more info terdapat judul akun, penjelasan singkat atau informasi tambahan terkait akun, tombol abjad untuk menuju ke halaman daftar akun, tombol home untuk menuju ke halaman awal menu A-Dict (IN-EN), tombol list untuk menuju ke halaman daftar abjad (list), serta tombol previous untuk menuju ke halaman penjelasan akun.

Menu A-Dict (EN-IN) merupakan kamus akun dengan Bahasa Inggris-Bahasa Indonesia. Menu A-Dict (EN-IN) memuat nama-nama akun, istilah Indonesia, saldo normal akun, penggolongan akun, klasifikasi akun dalam laporan keuangan, dan penjelasan singkat mengenai akun. Berikut ini spesifikasi menu A-Dict (EN-IN): (1) pada halaman awal menu A-Dict (EN-IN) terdapat judul menu A-DICT dan subjudul English-Indonesian, tombol menu untuk menuju ke halaman menu, serta tombol skip untuk menuju ke halaman petunjuk ADict; (2) pada halaman petunjuk terdapat judul "Petunjuk", uraian tentang petunjuk penggunaan menu A-Dict, tombol skip untuk melewati halaman petunjuk ke halaman utama menu A-Dict (EN-IN), tombol next untuk menuju ke halaman petunjuk selanjutnya, tombol previous untuk menuju ke halaman petunjuk sebelumnya, serta tombol finish untuk menuju ke halaman utama A-Dict; (3) pada halaman list terdapat judul halaman "List", tombol home untuk menuju ke halaman depan A-Dict (EN-IN), serta tombol abjad (A sampai Z) untuk menuju ke halaman daftar akun berdasarkan abjad; (4) pada halaman daftar akun terdapat tombol home untuk menuju ke halaman depan menu A-Dict (EN-IN), tombol list untuk menuju ke halaman list/daftar abjad, serta tombol akun yang sudah diurutkan berdasarkan abjad untuk menuju ke halaman penjelasan akun; (5) pada halaman penjelasan akun terdapat judul akun, penjelasan mengenai istilah Indonesia akun, saldo normal akun, kelompok akun, dan pelaporan akun di laporan keuangan, tombol abjad untuk menuju ke halaman daftar akun, tombol home untuk menuju ke halaman awal menu A-Dict (EN-IN), tombol list untuk menuju ke halaman daftar abjad (list), serta tombol more info untuk menuju ke halaman penjelasan singkat mengenai akun terkait; dan (6) pada halaman more info terdapat judul akun, penjelasan singkat atau informasi tambahan terkait akun, tombol abjad untuk menuju ke halaman daftar akun, tombol home untuk menuju ke halaman awal menu A-Dict (EN-IN), tombol list untuk menuju ke halaman daftar abjad (list), serta tombol previous untuk menuju ke halaman penjelasan akun.

Menu A-Link merupakan menu yang khusus untuk mempelajari pengaruh transaksi keuangan terhadap perubahan akun yang terdiri dari narasi transaksi dan tombol pengaruh akun. Jumlah transaksi keuangan ada 25 transaksi, dimana tarnsaksi tersebut merupakan transaksi perusahaan jasa. Spesifikasi A-Link adalah sebagai berikut: (1) pada halaman awal terdapat judul menu A-Link, tombol menu untuk kembali ke halaman menu, serta tombol next 
untuk menuju ke halaman petunjuk A-Link; (2) pada halaman petunjuk A-Link terdapat judul "petunjuk", uraian petunjuk penggunaan A-Link, tombol skip untuk langsung menuju ke halaman utama A-Link, tombol next untuk menuju ke halaman petunjuk selanjutnya, tombol previous untuk menuju ke halaman petunjuk sebelumnya, serta tombol finish untuk menuju ke halaman soal A-Link; (3) pada halaman soal A-Link terdapat nomor urut soal, narasi transaksi keuangan perusahaan jasa, 3 (tiga) pilihan kemungkinan perubahan posisi akun yang diakibatkan oleh transaksi terkait dimana ada (dua) pilihan jawaban salah dan 1 (satu) pilihan jawaban benar, serta tombol home untuk menuju ke halaman depan A-Link; (4) pada halaman respon salah terdapat emotikon dan caption untuk mengekspresikan jawaban salah, serta tombol click me untuk menuju ke halaman pembahasan soal; (5) pada halaman pembahasan soal jawaban yang salah terdapat narasi transaksi keuangan perusahaan jasa, pembahasan atas tarnsaksi keuangan terkait, tombol home untuk menuju ke halaman depan menu A-Link, serta tombol click me untuk menuju ke halaman soal; dan (6) pada halaman pembahasan untuk jawaban benar terdapat narasi transaksi perusahaan, pembahasan atas transaksi keuangan, tombol home untuk menuju ke halaman depan A-Link, serta tombol next item untuk menuju ke halaman soal selanjutnya.

Menu A-Toon merupakan menu untuk mempelajari seputar akun yang ditampilkan berupa cerita bergambar. Spesifikasi menu A-Toon adalah sebagai berikut: (1) pada halaman depan terdapat judul menu A-Toon, tombol menu untuk menuju ke halaman menu, tombol next untuk menuju ke halaman daftar isi; (2) pada halaman daftar isi terdapat judul "Daftar Isi", tombol go untuk menuju ke halaman tertentu yang dituju, tombol home untuk menuju ke halaman depan menu A-Toon, serta tombol next untuk menuju ke halaman selanjutnya; (3) pada tampilan halaman petunjuk terdapat judul "Petunjuk", uraian petunjuk penggunaan AToon, tombol home untuk menuju ke halaman depan menu A-Toon, serta tombol next untuk menuju ke halaman selanjutnya; (4) pada halaman daftar pemain terdapat nama dan gambar tokoh, tombol home untuk menuju ke halaman depan menu A-Toon, tombol previous untuk kembali ke halaman sebelumnya, serta tombol next untuk menuju ke halaman selanjutnya; (5) pada halaman sampul cerita terdapat judul cerita, tombol home untuk menuju ke halaman depan menu A-Toon, tombol previous untuk kembali ke halaman sebelumnya, serta tombol next untuk menuju ke halaman selanjutnya; (6) pada halaman cerita terdapat cerita bergambar, tombol home untuk menuju ke halaman depan menu A-Toon, tombol previous untuk kembali ke halaman sebelumnya, tombol next untuk menuju ke halaman selanjutnya, serta nomor halaman cerita; dan (7) pada halaman epilog terdapat juduk "epilog", kesimpulan yang disajikan dalam bentuk cerita bergambar, tombol home untuk menuju ke halaman depan menu 
A-Toon, tombol previous untuk kembali ke halaman sebelumnya, tombol next untuk menuju ke halaman selanjutnya, serta nomor halaman.

Menu pendukung MANSAE terdiri dari menu Profile, Help, Credit, dan About. Menu pendukung profile merupakan menu yang menampilan profil singkat pengembang. Menu pendukung help merupakan menu yang menampilkan petunjuk umum penggunaan MANSAE. Menu pendukung credit merupakan menu yang manmpilkan sumber dan referensi materi yang digunakan dalam MANSAE. Terakhir, menu pendukung about merupakan menu yang menampilkan uraian singkat mengenai media MANSAE.

Setelah tahap pengembangan produk, maka tahap selanjutnya adalah tahap validasi yang dilakukan oleh ahli media dan ahli materi. Pada validasi yang dilakukan oleh ahli media, aspek penilaian yang dinilai adalah aspek aplikasi (teknis penggunaan), dan aspek surface feature (tampilan). Berdasarkan penilaian tersebut komponen umum (general), A-Dict (INEN), A-Dict (EN-IN), A-Link, A-Toon, feedback, help, about, dan profile mendapatkan predikat sangat valid dengan perolehan nilai rata-rata 97,61\%. Nilai 97,61\% berarti bahwa media MANSAE baik dari segi aplikasi maupun tampilan sudah sangat layak dan menarik untuk digunakan sebagai media pembelajaran akun dan pengaruh transaksi keuangan terhadap perubahan akun. Lalu untuk data kualitatif yang diperoleh dari saran, komentar, dan pendapat secara umum tentang media pembelajaran dapat ditarik kesimpulan bahwa media MANSAE sudah cukup bagus baik dari segi desain maupun idenya, namun perlu diberi menu tambahan untuk sumber rujukan/referensi. Rekomendasi dari ahli media terhadap MANSAE adalah valid dan tanpa perlu direvisi.

Pada validasi yang dilakukan oleh ahli materi, aspek penilaian yang dinilai adalah aspek aplikasi (teknis penggunaan), language and grammar (bahasa dan tata bahasa), subject matter (materi pembelajaran yang dimuat), off-line material (petunjuk penggunaan menu). Berdasarkan penilaian tersebut komponen umum (general) dan feedback mendapatkan predikat sangat valid, sementara A-Dict (IN-EN), A-Dict (EN-IN), A-Link, A-Toon, help, about, dan profile mendapatkan predikat valid. Nilai rata-rata akhir dari ahli materi adalah $88,70 \%$. Artinya, berdasarkan penilaian secara keseluruhan materi dalam komponen MANSAE sangat sesuai dan layak digunakan. Sementara data kualitatif yang diperoleh dari saran, komentar, dan pendapat secara umum tentang media pembelajaran dapat ditarik kesimpulan bahwa materi dalam media MANSAE sangat menarik digunakan sebagai media pembelajaran dalam mengenal akun-akun.

Setelah melakukan uji validitas, maka dilakukan revisi berdasarkan saran dan masukan dari ahli media dan ahli materi. Adapun setelah dilakukan revisi, langkah selanjutnya adalah 
uji pengguna terbatas. Pada uji pengguna terbatas, aspek penilaian yang dinilai adalah aspek aplikasi (teknis penggunaan), surface feature (tampilan), language and grammar (bahasa dan tata bahasa), subject matter (materi pembeljaran yang dimuat), off-line material (petunjuk penggunaan menu). Berdasarkan penilaian tersebut komponen umum (general), A-Dict (INEN), A-Dict (EN-IN), A-Link, A-Toon, feedback, help, about, dan profile mendapatkan predikat sangat valid dengan perolehan nilai rata-rata akhir adalah 95,50\%. Artinya, menurut pengguna/siswa media MANSAE sangat sesuai dan layak digunakan untuk mempelajari materi akun dan pengaruh transaksi keuangan terhadap perubahan akun. Sementara dari data kualitatif yang diperoleh dari saran, komentar, dan pendapat secara umum tentang media pembelajaran dapat ditarik kesimpulan bahwa materi dalam media MANSAE sangat menarik digunakan sebagai media pembelajaran dalam mengenal akun-akun dan memahami materi pengaruh transaksi keuangan terhadap perubahan akun. Selain itu, pengoperasian dan bahasa yang digunakan dalam MANSAE juga cukup mudah dipahami. Namun, alur dalam menu AToon cukup sulit dipahami.

Adapun hasil validasi yang dilakukan ahli media, ahli materi, dan pengguna terbatas jika diringkas dapat dilihat pada tabel 2.

\begin{tabular}{llll}
\multicolumn{4}{l}{ Tabel 2. Ringkasan Hasil Validasi Ahli Media, Ahli Materi, dan Pengguna Terbatas } \\
\hline No. & Validator & Persentase (\%) & Keterangan \\
\hline 1. & Ahli Media & $97,61 \%$ & Sangat Valid \\
2. & Ahli Materi & $88,70 \%$ & Sangat Valid \\
3. & Pengguna Terbatas & $95,50 \%$ & Sangat Valid \\
& Rata-rata Keseluruhan Validasi & $93,94 \%$ & Sangat Valid \\
\hline
\end{tabular}

(Sumber: Diolah Peneliti, 2016)

Berdasarkan tabel 2 diketahui bahwa rata-rata keseluruhan nilai validasi adalah 93,94\%, yang artinya media MANSAE layak untuk digunakan sebagai media pembelajaran akun-akun dan pengaruh transaksi keuangan perusahaan jasa terhadap perubahan akun.

\section{PEMBAHASAN}

Berdasarkan menu-menu yang dikembangkan dalam MANSAE maka aspek-aspek yang perlu dikaji yaitu aspek teknis/aplikasi, surface features, language and grammar, subject matter, dan offline material. Pengkajian aspek-aspek tersebut adalah sebagai berikut.

\section{Aspek Teknis/Aplikasi}

Penilaian terhadap aspek teknis dilakukan terhadap 2 (dua) indikator, yaitu indikator instalasi dan indikator pengoperasian. Berdasarkan hasil uji coba terhadap siswa menunjukkan bahwa dari indikator instalasi mendapatkan nilai kelayakan sebesar 89,40\%. Hal ini menunjukkan bahwa siswa tidak mengalami kesulitan dalam melakukan penginstalan 
MANSAE pada smartphone mereka. Namun untuk mencapai $100 \%$ dalam penilaian kelayakan kemudahan penginstalan masih dibutuhkan 10,60\% lagi, hal ini tidak tercapai diduga dikarenakan ukuran file MANSAE yang cukup besar sehingga sulit diinstal pada smartphone yang memiliki ukuran RAM kecil atau sisa ukuran RAM yang minim.

Selain indikator penginstalan, indikator pengoperasian juga dinilai oleh siswa. Berdasarkan hasil uji coba kepada siswa diketahui bahwa untuk indikator pengoperasian MANSAE mendapatkan nilai sebesar 97,70 \%. Hal ini menunjukkan bahwa aplikasi MANSAE tidak mudah macet/ berhenti saat digunakan dan aplikasi MANSAE tidak rumit dalam penggunaannya. Sementara untuk 2,30\% yang tidak dapat diperoleh diduga diakibatkan karena aplikasi MANSAE diinstal pada smartphone dengan RAM yang kecil sehingga pada saat digunakan kadang mengalami proses loading yang cukup lama dari seharusnya.

Oleh karena itu, berdasarkan kedua penilaian indikator tersebut maka diketahui perolehan untuk aspek kualitas teknis/aplikasi adalah 93,55\% yang berarti bahwa media MANSAE mudah diinstal, mudah dioperasikan, dan tidak mudah macet/berhenti saat dioperasikan. Hal ini sesuai dengan pendapat Walker \& Hess serta Norwegian Centre for ICT in Education. Walker \& Hess dalam Arsyad (2005: 176) menjelaskan bahwa salah satu indikator kualitas teknis suatu media pembelajaran adalah kemudahan penggunaannya.

Selain itu, Norwegian Centre for ICT in Education (2012: 9) juga menyatakan bahwa digital learning resources provide ample opportunity for adapting the learning needs of different pupils within a number of skill areas, whether written, visual, auditory, and so forth. Designing accessible digital learning resources is a question of enabling as many pupils as possible to use the resources, independent of their capabilities. A prerequisite for such adaptation is that the digital learning resources have been designed in accordance with the principles of universal design. Universal design is the design of products and environments in such a way that they, as much as possible, can be used by everyone without the need for adaptation or a special design.

Maksud dari penjelasan Norwegian Centre for ICT in Education (2012: 9), yaitu bahwa sumber pembelajaran digital seharusnya dapat menyediakan kesempatan yang luas untuk menyesuaikan dengan kebutuhan belajar siswa yang berbeda-beda kemampuannya, apakah tertulis, visual, audio, dan lain sebagainya. Merancang sumber belajar digital yang mudah dioperasikan berarti mempertanyakan kemungkinan seberapa banyak siswa yang mungkin akan menggunakan sumber belajar, tidak tergantung pada kemampuan yang mereka miliki. Salah satu persyaratan untuk mengembangkan sumber pembelajaran adalah sumber 
pebelajaran tersebut dirancang sesuai dengan prinsip desain universal. Desain universal merupakan desain produk yang memungkinkan sebanyak mungkin orang dapat menggunakan tanpa perlu beradaptasi atau desain khusus.

\section{Aspek Surface Feature}

Aspek surface feature merupakan aspek penilaian media dari segi tampilan yang terlihat bukan dari segi pengejaan ataupun tata bahasanya. Dalam melakukan penilaian terhadap MANSAE, peneliti menggunakan 3 (tiga) indikator, yaitu displays, text quality, dan input. Indikator displays terkait dengan estetika tampilan media, indikator text quality terkait dengan penggunaan teks dalam media, dan indikator input terkait dengan penggunaan tombol-tombol dalam media.

\section{Display (Tampilan)}

Berdasarkan hasil uji coba terhadap siswa menunjukkan bahwa dari indikator displays mendapatkan nilai kelayakan sebesar 93,64\%. Hal ini menunjukkan bahwa secara tampilan media MANSAE sudah menarik, desain layout (pewarnaan dan gambar) sudah sesuai dan tepat, serta theme song yang digunakan juga sudah menarik. Berdasarkan penilaian tersebut maka masih dibutuhkan nilai 6,36\% lagi untuk mencapai $100 \%$, hal ini tidak tercapai diduga disebabkan karena sebagian kecil siswa kurang tertarik dengan desain tampilan maupun theme song yang ada dalam MANSAE atau mungkin dikarenakan desain tidak sesuai dengan selera siswa tersebut.

Sebagian besar warna latar belakang (background) pada MANSAE menggunakan warna hijau dan biru. Warna-warna ini digunakan karena menurut pendapat Kemmis (2013:http://www.empower-yourself-with-color-psychology.com/) bahwa the color blue induces calm and peace within us, yang artinya warna biru membuat diri kita menjadi tenang dan damai. Selanjutnya Kemmis (2013:http://www.empower-yourself-with-colorpsychology.com/) juga menjelaskan bahwa green is the great balancer of our mental, emotional and physical energies which is why there is so much green on our planet, yang artinya hijau merupakan penyeimbang terbaik mental, emosi, dan energi jasmani sehingga itulah mengapa banyak sekali warna hijau di planet kita.

Selain itu pengaturan tampilan informasi akun dengan penjelasan akun yang ditampilkan dihalaman yang berbeda dimaksudkan untuk menghindari kepadatan teks yang akan mengurangi estetika dan kenyamanan ketika membaca. Hal ini sesuai dengan pendapat Alessi (1991: 368), yaitu pay attention to the aesthetic quality of each display. Display should be uncluttered, without too much information being shown at once, and should be relevant to the goals of lesson. Artinya, perhatikan kualitas estetika setiap penyajian. Penyajian seharusnya 
rapi, tanpa terlalu banyak informasi yang ditampilkan dalam sekali waktu, dan seharusnya relevan dengan tujuan pembelajaran. Prince Edward Island Department of Education (2008: 31) juga menjelaskan bahwa the material is presented in a well-organized, consistent, and predictable fashion. Maksudnya adalah bahwa materi sebaiknya disajikan dalam susunan yang baik, konsisten, cara yang dapat diprediksi.

Penulisan caption pada halaman respon jawaban salah di menu A-Link disesuaikan dengan penggunaan emoticon. Hal ini dilakukan karena mengacu pada pendapat Prince Edward Island Department of Education (2008: 30) yang menyatakan bahwa what is said or written should clearly correspond to what is shown. Captions should be clear and relevant. Visuals should be placed to effectively support textual content and not interfere with reading or viewing. Artinya, apa yang dikatakan atau tertulis seharusnya berhubungan jelas dengan apa yang ditunjukkan. Captions seharusnya jelas dan relevan. Gambar seharusnya ditempatkan untuk mendukung konten tekstual secara efektif dan tidak menggangu kualitas keterbacaan dan penglihatan.

\section{Text Quality (Kualitas Teks)}

Berdasarkan hasil uji coba terhadap siswa menunjukkan bahwa dari indikator text quality mendapatkan nilai kelayakan sebesar 94,66\%. Hal ini menunjukkan bahwa jenis dan ukuran font (huruf) sudah sesuai dan tepat, tulisan sudah jelas/tampak dengan baik, ukuran gambar dalam MANSAE sudah sesuai dan tepat, serta penggunaan gambar MANSAE sudah sesuai. Sementara itu, untuk nilai sebesar 5,34\% tidak dapat dicapai untuk menghasilkan nilai 100\% diduga diakibatkan oleh siswa kurang berkenan dengan penggunaan gambar pada menu A-Toon. Hal ini diketahui karena pada nilai indikator text qualiy pada menu A-Toon mendapatkan nilai terendah dibandingkan menu lainnya, yaitu sebesar 87,13\%.

Penggunaan huruf pada MANSAE rata-rata lebih dari $18 \mathrm{pt}$, hal ini dilakukan agar ketika aplikasi digunakan pada smartphone dengan layar yang tidak terlalu lebar tidak akan mengurangi kualitas keterbacaan teks. Hal ini serupa dengan pendapat Walker \& Hess dalam Arsyad (2005: 176) bahwa salah satu kriteria dalam mengevaluasi kualitas perangkat lunak pembelajaran adalah kualitas teknisnya, yaitu keterbacaan, artinya suatu media harus memperhatikan ukuran dan jenis huruf agar pesan dalam media dapat disampaikan dengan baik.

Informasi singkat dan penjelasan akun di menu A-Dict disajikan pada halaman yang berbeda, hal ini dilakukan untuk menghindari kepadatan teks yang akan mengurangi kualitas dan manfaat teks yang ditampilkan serta untuk menghindari scrolling. Hal ini sesuai dengan pendapat Alessi (1991: 35) yang menyatakan bahwa extended texts of more than a page or 
two should alert you to potential problems. They mey overload memory, cause confusion, or decrease interest. Maksud dari pernyataan Alessi ini adalah teks yang disajikan lebih dari satu atau dua halaman akan meyebabkan siswa beban memori yang terlalu berat, menyebabkan kebingungan, atau mengurangi ketertarikan. Kemudian Alessi (1991:31) juga menambahkan bahwa scrolling should always be avoided. Scrolling is disconcerting because when text is moving it is so hard to distinguish the boundary between new information and old. Lastly, with scrolling, informasion at the top of the display disappears automatically with the result that important information is sometimes erased unintentionally. Maksudnya adalah penggunaan scrolling harus dihindari. Scrolling akan membuat bingung karena ketika teks bergerak akan sulit membedakan batas antara informasi baru dengan informasi lama. Selain itu dengan penggunaan scrolling akan membuat informasi yang terletak di bagian atas akan hilang sehingga mengakibatkan informasi penting akan tidak sengaja terhapus.

\section{Input (Masukan)}

Tombol-tombol yang digunakan dalam MANSAE dibuat sesuai dengan kebutuhan dan dijaga keakuratan setiap output dari masing-masing tombol. Berdasarkan uji coba kepada siswa diketahui bahwa untuk indikator input mendapatkan nilai sebesar 98,95\%. Hal ini menunjukkan bahwa setiap tombol dalam MANSAE sudah memberikan output yang benar dan sudah efektif dalam penggunaannya. Sementara untuk kekurangan nilai sebesar 1,05\% diduga karena pada saat siswa mengoperasikan aplikasi terjadi loading yang lebih lama dari seharusnya yang mungkin disebabkan oleh RAM pada smartphone berukuran kecil.

Terkait dengan keefektifan penginputan pada MANSAE yang sudah dikategorikan layak telah sesuai dengan pendapat Alessi (1991: 368) yang menjelaskan mengenai input pada media, bahwa input should also be designed so as to keep user typing or other physical action efficient. Artinya input seharusnya dirancang untuk menjaga agar ketika pengguna mengetik atau melakukan tindakan lainnya akan efisien. Selain itu Prince Edward Island Department of Education (2008:24) menambhakan bahwa in order to use a media effectively, and in order to get to the important information, a student must find a media navigable and easy to use. Maksudnya adalah agar penggunaan media berlangsung secara efektif, maka media harus mudah dioperasikan dan mudah diarahkan oleh siswa.

Oleh karena itu berdasarkan uji coba pada siswa yang diperoleh nilai sebesar 93,64\% dari indikator displays, 94,66\% dari indikator text quality, dan 98,95\% dari indikator input akan dihasilkan nilai rata-rata untuk aspek surface feature sebesar 95,75\%. Hal ini menunjukkan bahwa tampilan pada MANSAE sudah menarik, penggunaan tombol juga sudah 
efektif, namun ada sebagian kecil siswa yang kurang menyukai gambar yang digunakan pada menu A-Toon.

\section{Aspek Languange and Grammar}

Aspek language and grammar merupakan aspek penilaian untuk konsistensi penggunaan kata-kata dan tanda baca serta penilaian pada aspek ini harus memperhatikan tingkat dan gaya bahasa sasaran pengguna. Dalam aspek language and grammar ada 2 (dua) indikator yang akan dikaji, yaitu reading level dan spelling, grammar, and punctuation.

\section{Reading Level (Tingkat Membaca)}

Pada pengembangan MANSAE, bahasa yang digunakan pada pembahasan maupun pemberian informasi merupakan Bahasa Indonesia yang sederhana dengan menggunakan kosa kata yang juga sederhana. Hal ini dilakukan karena diharapkan pembahasan materi dalam MANSAE dapat dipahami pengguna dengan baik. Kemudian, berdasarkan hasil uji coba pengguna diperoleh angka sebesar 92,80\%. Angka sebesar 92,80\% ini menunjukkan bahwa bahasa yang digunakan dalam MANSAE mudah dipahami dan tidak menimbulkan ambigu. Namun, untuk angka sebesar 7,20\% yang tidak diperoleh untuk menggenapkan menjadi 100\% diduga diakibatkan oleh penggunaan bahasa yang kurang dapat dimengerti oleh beberapa siswa pada materi dalam menu A-Toon.

Terkait dengan penggunaan bahasa dalam menu MANSAE yang dikategorikan sudah sesuai ini telah selaras dengan pendapat Prince Edward Island Department of Education (2008: 37) yang menyatakan bahwa the use of specialized language should be suited to the context, maturity, and intellectual level of the audience. Artinya, penggunaan bahasa tertentu harus disesuaikan dengan konteks, kematangan, dan tingkat intelektual pengguna. Selain itu, Alessi (1991: 366) juga berpendapat bahwa you should familiarize yourself with the nature of the target population so that you will be able to judge whether the reading level of the lesson is appropriate. Artinya, anda seharusnya membiasakan diri dengan kebiasan target populasi sehingga anda akan mampu menilai apakah tingkat membaca pelajarannya sudah sesuai.

\section{Spelling, Grammar, and Punctuation (Pengejaan, Tata Bahasa, dan Tanda Baca)}

Tingkat kesesuaian serta kebenaran pengejaan, tata bahasa, dan tanda baca telah dinilai sebesar $80 \%$ oleh ahli materi, artinya baik ejaan, tata bahasa, dan tanda baca sudah benar penggunaanya. Pemeriksaan penggunaan ejaan, tata bahasa dan tanda baca oleh pihak lain ini sesuai dengan pendapat Alessi (1991: 367) bahwa it is usually a good idea for these to be checked by someone other than the author. We tend to miss our own errors in spelling, grammar, and punctuation. Maksudnya adalah sebaiknya ejaan, tata bahasa dan tanda baca diperiksa oleh orang lain, bukan si penulis. Hal ini dilakukan karena untuk menghindari 
kecenderungan untuk melewatkan kesalahan kita sendiri pada pengejaan, tata bahasa, dan tanda baca.

Oleh karena itu berdasarkan uji coba pada siswa yang diperoleh nilai sebesar 92,80\% dari indikator reading level dan $80 \%$ dari indikator spelling, grammar, and punctuation akan dihasilkan nilai rata-rata untuk aspek surface feature sebesar $86,40 \%$. Hal ini menunjukkan bahwa dari aspek language and grammar pada MANSAE sudah benar dan sesuai dengan tingkatan baca siswa, , namun ada beberapa penulisan ejaan dan tanda baca yang masih kurang tepat.

\section{Aspek Subject Matter}

Aspek subject matter merupakan aspek untuk menilai penekanan materi dalam media. Ada 3 (tiga) indikator yang akan dikaji pada aspek subject matter, yaitu goal and objective, content emphasis dan organization.

\section{Goals and Objective}

Tujuan pengembangan MANSAE adalah untuk mempermudah pemula di bidang akuntansi dalam mempelajari akun-akun. Berdasarkan uji coba terhadap siswa terkait dengan indikator goals and objective mendapatkan nilai sebesar 96,95\%. Nilai sebesar 96,95\% ini menunjukkan bahwa: (1) MANSAE merupakan media yang mudah dipahami dalam mempelajari akun dan pengaruh transaksi keuangan terhadap perubahan akun; (2) MANSAE mampu memotivasi siswa dalam mempelajari akun dan pengaruh transaksi keuangan terhadap perubahan akun; (3) MANSAE bermanfaat bagi siswa; serta (4) MANSAE mempermudah siswa dalam mempelajari akun-akun. Sementara untuk nilai sebesar 3,05\% yang tidak tercapai menunjukkan bahwa penggunaan MANSAE masih kurang membantu sebagian kecil siswa untuk memahami dan mempelajari materi akun dan pengaruh transaksi keuangan terhadap perubahan akun.

Dikarenakan MANSAE dari indikator goals and objective dikategorikan sudah mampu mencapai tujuan dipembelajaran yang diinginkan maka hal ini selaras dengan pendapat Arsyad (2005: 176) yang menyatakan bahwa media yang berkualitas harus mampu untuk memberikan kesempatan belajar bagi siswa, memberikan bantuan kepada siswa untuk belajar, dan mampu memotivasi siswa untuk belajar. Selain itu, Sungkono (2012: 5) juga menyebutkan bahwa dalam salah satu kriteria untuk mengukur kualitas materi dalam sebuah software (perangkat lunak) yaitu pengembangan software (perangkat lunak) tersebut harus sesuai dengan tujuan yang dirumuskan. 


\section{Content Emphasis (Penekanan Materi)}

Pada menu A-Dict materi yang ditekankan adalah materi mengenai akun-akun berupa istilah asing akun akuntansi, saldo normal, pengelompokan akun, klasifikasi akun dalam laporan keuangan, serta informasi singkat mengenai akun. Sementara pada menu A-Link memuat materi mengenai pengaruh transaksi keuangan terhadap perubahan akun. Lalu pada menu A-Toon memuat materi pengenai dasar-dasar dalam akuntansi yang harus diketahui oleh pemula di bidang akuntansi.

Penilaian oleh siswa saat uji pengguna terbatas memperoleh nilai sebesar 94,82\% yang artinya materi mengenai akun dan transaksi keuangan perusahaan jasa yang dituangkan sudah sesuai dengan kebutuhan peserta didik sebagai pemula yang mempelajari akuntansi. Sementara untuk nilai 5,18\% lainnya yang tidak diperoleh diduga diakibatkan pada penyajian materi A-Toon yang memiliki narasi cerita terlalu panjang di bagian awal cerita.

Penuangan materi dalam A-Dict telah sesuai degan pendapat Samryn (2011: 84) yang menjelaskan kompetensi dasar pemula di bidang akuntansi, 4 (empat) di antaranya: (1) menghafalkan nama-nama akun dalam neraca dan laporan laba rugi, sesuai bagan akun; (2) memahami arti, batasan, dan karakteristik tiap akun tersebut; (3) memahami mekanisme, kapan suatu akun harus dicatat di debit, dan kapan harus dicatat di kredit; dan (4) memahami penempatan tiap akun dalam neraca dan laba rugi, karena akun tidak boleh tertukar dalam laporan keuangan. Sementara itu materi A-Link dan A-Toon telah sesuai dengan pendapat Ikhsan (2012: 2) yang menyatakan bahwa ada unsur lain yang paling mendasar dalam akuntansi, yaitu persamaan dasar akuntansi yang melaporkan kondisi atau posisi keuangan dan bisnis perusahaan yang meliputi posisi aktiva, kewajiban, dan modal pemilik.

\section{Organization (Pengorganisasian)}

Pengorganisasian materi atau penyusunan materi yang dimuat dalam A-Toon kurang baik, menurut hasil dari uji pengguna menyatakan bahwa alur cerita dalam A-Toon cukup sulit dipahami. Hal ini terbukti dengan perolehan nilai sebesar $74,60 \%$ pada indikator organization pada menu A-Toon. Oleh karena itu revisi dilakukan untuk memperbaiki alur cerita yang terdapat dalam A-Toon sehingga pesan yang terdapat dalam A-Toon akan tersampaikan dengan baik. Hal ini selaras dengan pendapat Lestari dkk (2009: 1) yang menjelaskan bahwa komik adalah suatu bentuk seri yang menggunakan gambar-gambar tidak bergerak yang disusun sedemikian rupa sehingga membentuk jalinan cerita (alur). Sehingga dalam pembuatan komik harus memperhatikan alur cerita untuk memperjelas pesan yang ingin disampaikan. Selain itu Prince Edward Island Department of Education (2008:28) juga menyebutkan bahwa the order in which the information is presented is logical and suited to 
the subject and objectives. In both the teacher and student materials, the tasks are clearly defined and the information is accessible to a diverse range of abilities and achievement levels. Maksudnya adalah susunan informasi yang disampaikan harus logis dan sesuai dengan pelajaran dan tujuan pembelajaran. Selain itu, informasi juga harus mampu dipahami dengan mudah-baik oleh guru maupun siswa-meski terdapat perbedaan kemampuan maupun tingkat pencapaian.

\section{Aspek Offline Material}

Salah satu indikator yang dikaji dalam aspek ini adalah manual-lesson operation, yaitu panduan dalam mengoperasikan media. Berdasarkan uji coba pada siswa, aspek offline material mendapatkan nilai sebesar $96,35 \%$ yang menunjukkan bahwa panduan dalam mengoperasikan MANSAE beserta menu-menunya sudah mudah dipahami dan tidak menimbulkan ambigu. Namun untuk 3,65\% lainnya tidak dapat diperoleh diduga karena sebagian kecil siswa belum dapat memahami kalimat dan instruksi yang terdapat dalam halaman petunjuk MANSAE dan menu-menunya.

Pada media MANSAE, di setiap awal halaman utama diberikan petunjuk/panduan fungsi masing-masing tombol yang terdapat dalam setiap menu. Pemberian panduan dilakukan agar pengguna dapat mengoperasikan media dengan benar sesuai dengan yang diperintahkan. Hal ini sesuai dengan yang diungkapkan oleh Alessi (1991: 377) bahwa most manuals contain directions for making the lesson operational. Artinya sebagaian besar petunjuk penggunaan berisi petunjuk untuk membuat prosedur kerja pada pelajaran.

\section{SIMPULAN}

Media MANSAE mendapatkan penilaian dari ahli media sebesar 97,61\%, dari ahli materi sebesar $88,70 \%$, dan dari pengguna terbatas sebesar 95,50\%. Rata-rata dari ketiga penilaian tersebut adalah 93,94\%, yang artinya bahwa media MANSAE dari segi aplikasi, surface features, language and grammar, subject matter, dan offline material sudah sesuai dan layak digunakan sebagai media pembelajaran akun-akun untuk pemula di bidang akuntansi. Adapun keunggulan MANSAE adalah sebagai berikut: (a) memuat lebih dari 140 akun Indonesia-Inggris maupun Inggris-Indonesia yang dilengkapi saldo normal akun, kelompok akun, klasifikasi akun dalam laporan keuangan, serta penjelasan singkat mengenai akun tersebut; (b) mudah dioperasikan oleh siswa, karena menu maupun tombol mudah dipahami oleh siswa; serta (c) dapat digunakan di mana saja dan kapan saja. MANSAE juga memiliki beberapa kelemahan, kelemahan tersebut antara lain: (a) file MANSAE cukup besar, sehingga dalam mengoperasikan butuh RAM yang cukup besar; (b) dibutuhkan smartphone 
yang berbasis android untuk mengoperasikannya; serta (c) pada awal membuka aplikasi harus menunggu antara 10-20 detik untuk proses loading atau memuat isi dalam aplikasi.

Dalam pemanfaatan MANSAE disarankan agar: (a) dalam menginstal media MANSAE sebaiknya menggunakan menggunakan smartphone berbasis android dengan RAM minimal 768 MB dan layar 4 inchi; serta (b) dalam menggunakan media MANSAE sebaiknya menunggu \pm 15 detik dahulu untuk proses loading. Adapun untuk pengembangan lebih lanjut diharapkan MANSAE dapat dikembangkan dalam platform lain misalnya J2ME, Blackberry, iOS, dan Windows Phone. Selain itu bisa ditambahkan tombol search untuk mencari nama akun tertentu dan tombol add untuk menambahkan akun baru yang belum ada/tersedia dalam menu A-Dict.

\section{DAFTAR RUJUKAN}

Akbar, S. (2013). Instrumen Perangkat Pembelajaran. Bandung: PT Remaja Rosdakarya.

Alessi, S. M. \& Stanley, R. T. (1991). Computer-Based Instruction: Method and Development. New Jersey: Prentice Hall.

Arsyad, A. (2005). Media Pembelajaran. Jakarta: Raja Grafindo.

Christiani, T.(2012).Pengembangan Media Komik Geografi Topik Lingkungan untuk Siswa SMP Kelas VIII.Malang: Universitas Negeri Malang.

Handayati, P. (2009). Dasar-dasar Akuntansi.Malang: Universitas Negeri Malang.

Hasan, I. \& Susilowibowo, J. (2014). Pengembangan Kartu Pintar Sebagai Media Pembelajaran Materi Pokok Pengaruh Transaksi Keuangan Terhadap Perubahan Akunakun di SMK Negeri 1 Ngawi. Diakses dari http://ejournal.unesa.ac.id/jurnal/jpak/full/.

Ikhsan, A. (2012). Pengantar Praktis Akuntansi. Yogyakarta: Graha Ilmu.

Kemmis, J. S. (2013). Meaning of Colors. Diakses dari http://www.empower-yourself-withcolor-psychology.com/meaning-of-colors.html.

Lestari, dkk. (2009). Media Grafis. (2009). Diakses dari http://file.upi.edu.

Norwegian Centre for ICT in Education. (2012). Quality Criteria for Digital Learning Resources. Diakses dari iktsenteret.no.

Prince Edward Island Departemen of Education. (2008). Evaluation and Selection of Learning Resources: A Guide. Diakses dari www.gov.pe.ca.

Restuningdiah, N. \& Makaryanawati. (2012). Pengembangan Buku Saku Kamus dan Rumus Akuntansi Bilingual serta Buku Saku Kamus dan Rumus Ekonomi untuk SMA Jurusan IPS dan SMK. Malang: Universitas Negeri Malang.

Samryn, L. M. (2011). Pengantar Akuntansi: Mudah Membuat Jurnal dengan Pendekatan Siklus Transaksi. Jakarta: Rajawali Pers.

Sungkono.(2012).Evaluasi Media Pembelajaran. Diakses dari staff.uny.ac.id.

Wardhani, D. A. (2013). Pengantar Akuntansi I. Malang: Universitas Negeri Malang.

Weygandt, J. J., Kimmel, P. D., \& Kieso, D. E. (2011). Financial Accounting: IFRS Edition. United States of America: Wiley. 


\section{LAMPIRAN}

Tabel L1. Data Kuantitatif Validasi Ahli Media

\begin{tabular}{|c|c|c|c|}
\hline No. & $\begin{array}{c}\text { Komponen yang } \\
\text { Dinilai }\end{array}$ & $\begin{array}{c}\text { Persentase } \\
(\%)\end{array}$ & $\begin{array}{c}\text { Kriteria } \\
\text { Kevalidan }\end{array}$ \\
\hline \multirow[t]{5}{*}{1.} & General & & \\
\hline & Aplikasi & 85,00 & Sangat Valid \\
\hline & Surface & 100,00 & Sangat Valid \\
\hline & Features & 92,50 & Sangat Valid \\
\hline & Rata-rata & & \\
\hline \multirow[t]{5}{*}{2.} & A-Dict (IN-EN) & & \\
\hline & Aplikasi & 100,00 & Sangat Valid \\
\hline & Surface & 96,67 & Sangat Valid \\
\hline & Features & 98,33 & Sangat Valid \\
\hline & Rata-rata & & \\
\hline \multirow[t]{5}{*}{3.} & A-Dict (EN-IN) & & \\
\hline & Aplikasi & 100,00 & Sangat Valid \\
\hline & Surface & 96,67 & Sangat Valid \\
\hline & Features & 98,33 & Sangat Valid \\
\hline & Rata-rata & & \\
\hline \multirow[t]{5}{*}{4.} & A-Link & & \\
\hline & Aplikasi & 80,00 & Sangat Valid \\
\hline & Surface & 98,67 & Sangat Valid \\
\hline & Features & 89,33 & Sangat Valid \\
\hline & Rata-rata & & \\
\hline \multirow[t]{5}{*}{5.} & A-Toon & & \\
\hline & Aplikasi & 100,00 & Sangat Valid \\
\hline & Surface & 100,00 & Sangat Valid \\
\hline & Features & 100,00 & Sangat Valid \\
\hline & Rata-rata & & \\
\hline \multirow[t]{2}{*}{6.} & Balikan & 100,00 & Sangat Valid \\
\hline & (Feedback) & & \\
\hline \multirow[t]{5}{*}{7.} & Lain-lain & & \\
\hline & Feedback & 100,00 & Sangat Valid \\
\hline & Help & 100,00 & Sangat Valid \\
\hline & About & 100,00 & Sangat Valid \\
\hline & Profil & 100,00 & Sangat Valid \\
\hline 8. & Rata-rata & 97,61 & Sangat Valid \\
\hline
\end{tabular}

Tabel L2. Data Kuantitatif Validasi Ahli Materi

\begin{tabular}{|c|c|c|c|}
\hline No. & $\begin{array}{c}\text { Komponen yang } \\
\text { Dinilai }\end{array}$ & $\begin{array}{l}\text { Persentase } \\
(\%)\end{array}$ & $\begin{array}{c}\text { Kriteria } \\
\text { Kevalidan }\end{array}$ \\
\hline \multirow[t]{4}{*}{1.} & General & & \\
\hline & $\begin{array}{l}\text { Aplikasi } \\
\text { Languange and }\end{array}$ & 100,00 & Sangat Valid \\
\hline & Grammar & 80,00 & Valid \\
\hline & Rata-rata & 90,00 & Sangat Valid \\
\hline \multirow[t]{6}{*}{2.} & A-Dict (IN-EN) & & \\
\hline & Aplikasi & 80,00 & Valid \\
\hline & Languange and & & \\
\hline & Grammar & 80,00 & Valid \\
\hline & Subject Matter & 70,00 & Valid \\
\hline & Rata-rata & 76,67 & Valid \\
\hline \multirow[t]{6}{*}{3.} & A-Dict (EN-IN) & & \\
\hline & Aplikasi & 80,00 & Valid \\
\hline & Languange and & & \\
\hline & Grammar & 80,00 & Valid \\
\hline & Subject Matter & 70,00 & Valid \\
\hline & Rata-rata & 76,67 & Valid \\
\hline \multirow[t]{9}{*}{4.} & A-Link & & \\
\hline & Aplikasi & 80,00 & Valid \\
\hline & Surface & & \\
\hline & Features & 80,00 & Valid \\
\hline & Languange and & & \\
\hline & Grammar & 80,00 & Valid \\
\hline & $\begin{array}{l}\text { Subject Matter } \\
\text { Off-line }\end{array}$ & 80,00 & Valid \\
\hline & Material & 80,00 & Valid \\
\hline & Rata-rata & 80,00 & Valid \\
\hline \multirow[t]{8}{*}{5.} & A-Toon & & \\
\hline & Aplikasi & 80,00 & Valid \\
\hline & Surface & & \\
\hline & Features & 80,00 & Valid \\
\hline & Languange and & & \\
\hline & Grammar & 76,67 & Valid \\
\hline & Subject Matter & 63,33 & Valid \\
\hline & Rata-rata & 75,00 & Valid \\
\hline 6. & $\begin{array}{l}\text { Balikan } \\
\qquad(\text { Feedback })\end{array}$ & 100,00 & Sangat Valid \\
\hline 7. & Rata-rata & 88,70 & Sangat Valid \\
\hline
\end{tabular}


Tabel L3. Data Kuantitatif Validasi Pengguna Terbatas

\begin{tabular}{|c|c|c|c|}
\hline No. & $\begin{array}{l}\text { Komponen yang } \\
\text { Dinilai }\end{array}$ & $\begin{array}{l}\text { Persentase } \\
\quad(\%)\end{array}$ & $\begin{array}{c}\text { Kriteria } \\
\text { Kevalidan }\end{array}$ \\
\hline \multirow[t]{7}{*}{1.} & General & & \\
\hline & Aplikasi & 90,35 & Sangat Valid \\
\hline & Surface Features & & \\
\hline & Languange and & 88,60 & Sangat Valid \\
\hline & Grammar & & \\
\hline & Rata-rata & 96,00 & Sangat Valid \\
\hline & & 91,65 & Sangat Valid \\
\hline \multirow[t]{9}{*}{2.} & A-Dict (IN-EN) & & \\
\hline & Aplikasi & 98,60 & Sangat Valid \\
\hline & Surface Features & & \\
\hline & Languange & 96,19 & Sangat Valid \\
\hline & Grammar & & \\
\hline & Subject Matter & 96,00 & Sangat Valid \\
\hline & Offline-Material & 99,30 & Sangat Valid \\
\hline & Rata-rata & 98,60 & Sangat Valid \\
\hline & & 97,74 & Sangat Valid \\
\hline \multirow[t]{9}{*}{3.} & A-Dict (EN-IN) & & \\
\hline & Aplikasi & 100,00 & Sangat Valid \\
\hline & Surface Features & & \\
\hline & Languange & 96,74 & Sangat Valid \\
\hline & Grammar & & \\
\hline & Subject Matter & 96,00 & Sangat Valid \\
\hline & Offline-Material & 96,00 & Sangat Valid \\
\hline & Rata-rata & 97,40 & Sangat Valid \\
\hline & & 97,23 & Sangat Valid \\
\hline \multirow[t]{9}{*}{4.} & A-Link & & \\
\hline & Aplikasi & 100,00 & Sangat Valid \\
\hline & Surface Features & & \\
\hline & Languange & 96,99 & Sangat Valid \\
\hline & Grammar & & \\
\hline & Subject Matter & 96,00 & Sangat Valid \\
\hline & Offline-Material & 97,40 & Sangat Valid \\
\hline & Rata-rata & 96,00 & Sangat Valid \\
\hline & & 97,28 & Sangat Valid \\
\hline
\end{tabular}

5. A-Toon

$\begin{array}{lcc}\text { Aplikasi } & 98,60 & \text { Sangat Valid } \\ \begin{array}{l}\text { Surface Features } \\ \text { Languange and }\end{array} & 91,14 & \text { Sangat Valid } \\ \text { Grammar } & & \\ \text { Subject Matter } & 80,00 & \text { Valid } \\ \text { Offline-Material } & 80,60 & \text { Valid } \\ \quad \text { Rata-rata } & 93,40 & \text { Sangat Valid } \\ & 88,75 & \text { Sangat Valid }\end{array}$

6. Lain-lain

Balikan (Feedback) $\quad 96,95 \quad$ Sangat Valid

Help $\quad 96,00 \quad$ Sangat Valid

About $\quad 97,40 \quad$ Sangat Valid

Profil 97,40 Sangat Valid

Credit $\quad 94,60 \quad$ Sangat Valid

7. Rata-rata $95,50 \quad$ Sangat Valid

